\title{
Саттарова В.C.
}

\section{Организация исследовательской деятельности студентов колледжей через систему зачетных единиц на примере предмета: математика}

\section{Sattarova V.S. \\ Organization of research activities of college students through a system of credits as an example the subject of mathematics}

В докладе говорится о применении понятия зачетных единиц в исследовательской деятельности студентов колледжей Ключевые слова: исследовательская деятельность, зачетная единица

\section{Саттарова Виктория Сергеевна}

Преподаватель

Курский государственный политехнический колледж

2. Курск, ул. Народная, 8
The report refers to the application of the concept of credits in the research activities of college students

Key words: research activities, credit unit

\author{
Sattarova Viktoriya Sergeevna \\ Teacher \\ Kursk state technical college \\ Kursk, Narodnaya st., 8
}

Повышение качества образования и формирование у студентов ключевых компетенций - важнейшая задача модернизации образования, которая предполагает формирование активной самостоятельной позиции студентов; развитие общеучебных умений и навыков; а так же специальных знаний и умений.

Формирование исследовательских умений студентов является одной из самых актуальных проблем, так как федеральный государственный образовательный стандарт предполагает формирование умения студентов самих получать ответы на поставленные вопросы. Выпускник должен уметь самостоятельно мыслить, видеть и творчески решать возникающие проблемы.

Под учебно-исследовательской деятельностью студентов колледжей понимают деятельность, связанную с поиском ответа на творческую, исследовательскую задачу с заранее неизвестным решением. Можно выделить два направления организации исследовательской деятельности студентов: предметная исследовательская деятельность; проектирование и организация исследовательской деятельности.

- предметная исследовательской деятельности включает алгоритм организации цикла учебного исследования (т. е. что, как и в какой последовательности делает студент). В процессе исследовательской деятельности реализу- 
ются следующие этапы: постановка проблемы, изучение теории, связанной с выбранной темой, выдвижение гипотезы исследования, подбор методик и практическое овладение ими, сбор собственного материала, его анализ и обобщение, собственные выводы.

Таблица 1. Рамка квалификаций для построения индивидуальной образовательной траектории при освоении программы подготовки специалистов среднего звена по предмету математика

\begin{tabular}{|c|c|c|c|c|}
\hline № & $\begin{array}{c}\text { Наименование } \\
\text { ПМ/МДК }\end{array}$ & $\begin{array}{c}\text { Курс } / \\
\text { се- } \\
\text { местр }\end{array}$ & $\begin{array}{c}\text { Зачетная } \\
\text { единица (ВВД) }\end{array}$ & $\begin{array}{c}\text { Проверяемые дескрипторы квали- } \\
\text { фикационного уровня }\end{array}$ \\
\hline \multirow[t]{5}{*}{1.} & \multirow{5}{*}{$\begin{array}{l}\text { Развитие понятия о } \\
\text { числе, корне, степе- } \\
\text { ни, логарифме }\end{array}$} & \multirow[t]{5}{*}{$1 / 1$} & \multirow{5}{*}{$\begin{array}{l}\text { Составление книги по за- } \\
\text { данным параметрам на } \\
\text { примере темы: Развитие } \\
\text { понятия о числе, корне, } \\
\text { степени, логарифме. }\end{array}$} & 1.Создание электронной почты. \\
\hline & & & & $\begin{array}{l}\text { 2. Регистрация в проекте (элек- } \\
\text { тронное письмо преподавателю). }\end{array}$ \\
\hline & & & & $\begin{array}{l}\text { 3. Получение задания по электрон- } \\
\text { ной почте. }\end{array}$ \\
\hline & & & & $\begin{array}{l}\text { 4. Оформление статьи по заданным } \\
\text { параметрам. }\end{array}$ \\
\hline & & & & 5. Оформление книги. \\
\hline \multirow[t]{3}{*}{2.} & \multirow{3}{*}{$\begin{array}{l}\text { Сборник научно - } \\
\text { фантастических со- } \\
\text { чинений - Новая } \\
\text { геометрия. }\end{array}$} & \multirow[t]{3}{*}{$1 / 1$} & \multirow{3}{*}{$\begin{array}{l}\text { Оформление журнала и } \\
\text { написание рекламного } \\
\text { слогана согласно с основ- } \\
\text { ными понятиями геомет- } \\
\text { рии. }\end{array}$} & 1.Написание рекламного слогана. \\
\hline & & & & $\begin{array}{l}\text { 2. Написание сочинения (Привлека- } \\
\text { ется учитель русского языка). }\end{array}$ \\
\hline & & & & 3. Оформление журнала. \\
\hline \multirow[t]{3}{*}{3.} & \multirow{3}{*}{$\begin{array}{l}\text { Мультимедийный } \\
\text { продукт: Тригоно- } \\
\text { метрия в окружаю- } \\
\text { щем нас мире и жиз- } \\
\text { ни человека. }\end{array}$} & \multirow[t]{3}{*}{$1 / 2$} & \multirow{3}{*}{$\begin{array}{l}\text { Подготовка мультиме- } \\
\text { диа продукта на приме- } \\
\text { ре темы: Тригономет- } \\
\text { рия в окружающем нас } \\
\text { мире и жизни человека. }\end{array}$} & $\begin{array}{l}1 . \quad \text { Подбор, анализ и осмысление } \\
\text { информации, выделение главной } \\
\text { мысли. }\end{array}$ \\
\hline & & & & $\begin{array}{l}\text { 2. Подготовка презентации, букле- } \\
\text { та. }\end{array}$ \\
\hline & & & & 3. Защита проекта. \\
\hline \multirow[t]{5}{*}{4.} & \multirow[t]{5}{*}{$\begin{array}{l}\text { Рекомендации по } \\
\text { нахождению произ- } \\
\text { водной и интеграла. }\end{array}$} & \multirow[t]{5}{*}{$1 / 2$} & \multirow{5}{*}{$\begin{array}{l}\text { Подготовка пакета ре- } \\
\text { комендаций по нахож- } \\
\text { дению производных и } \\
\text { интегралов в онлайн - } \\
\text { калькуляторах } \\
\text { (Wolfram|Alpha), про- } \\
\text { граммах на телефоне. }\end{array}$} & $\begin{array}{l}\text { 1.0пределение основных программ } \\
\text { по вычислению производной и ло- } \\
\text { гарифма. }\end{array}$ \\
\hline & & & & $\begin{array}{l}\text { 2. Выделение основных этапов ра- } \\
\text { боты с онлайн калькуляторами. }\end{array}$ \\
\hline & & & & $\begin{array}{l}\text { 3. Выделение основных особенно- } \\
\text { стей набора математических сим- } \\
\text { волов. }\end{array}$ \\
\hline & & & & $\begin{array}{l}\text { 4. Определение недостатков каль- } \\
\text { кулятора. }\end{array}$ \\
\hline & & & & $\begin{array}{l}\text { 5. Оформление рекомендаций по } \\
\text { нахождению производных и инте- } \\
\text { гралов в онлайн - калькуляторе. }\end{array}$ \\
\hline \multirow[t]{3}{*}{5.} & \multirow{3}{*}{$\begin{array}{l}\text { Функции, много- } \\
\text { гранники, тела вра- } \\
\text { щения вокруг нас. }\end{array}$} & \multirow[t]{3}{*}{$1 / 2$} & \multirow{3}{*}{$\begin{array}{l}\text { Подготовка серии фото } \\
\text { основанных на сравни- } \\
\text { тельно - сопостави- } \\
\text { тельном анализе окру- } \\
\text { жающих предметов и } \\
\text { математических поня- } \\
\text { тий. }\end{array}$} & $\begin{array}{l}\text { 1.Фотографирование окружающих } \\
\text { предметов. }\end{array}$ \\
\hline & & & & 2. Подбор математических понятий. \\
\hline & & & & 3. Оформление выставки. \\
\hline
\end{tabular}


- проектирование и организация исследовательской деятельности - определяет существенные элементы исследовательской деятельности, воспроизводство которых позволяет фиксировать ее наличие в реальной практике.

В условиях колледжа главной функцией исследовательской деятельности может быть организация на ее основе профильного обучения, поэтому здесь необходима разработка курсов по выбору, введение в базисную сетку часов на выполнение исследовательских проектов, организации системы индивидуального консультирования и защиты этих проектов. Очевидно, что задачи и формы исследовательской деятельности должны соответствовать специальности студентов, специфике познавательной мотивации, в противном случае учебные исследования могут оказаться неэффективными и даже вредными.

Зачетные единицы в исследовательской деятельности - это своего рода «евро», «общая валюта» в сфере образования. Чтобы результаты обучения были сравнимы, их надо оценивать в рамках некоторой общей системы.

Рассмотрим подробнее основные смысловые компоненты организации исследовательской деятельности студентов на основе внедрения зачетных единиц.

Определяются основные понятия, используемые при организации исследовательской деятельности студентов через зачетные единицы.

Учебное исследование - образовательный процесс, реализуемый на основе технологии исследовательской деятельности.

Исследовательское поведение - одна из фундаментальных форм взаимодействия живых существ с реальным миром, направленная на его познание, сущностную характеристику деятельности человека.

Учебное исследование и научное исследование, главная цель, которого заключается в приобретении студентами функционального навыка исследования как универсального способа освоения действительности, развитии способности к исследовательскому типу мышления, активизации личностной позиции в образовательном процессе на основе приобретения субъективно новых знаний.

В развитии исследовательской деятельности учащихся и студентов в России имеются давние традиции. Так, во многих регионах создавались и функционировали юношеские научно-технические общества. В современных условиях значение термина «исследовательская деятельность» приобретает несколько иное значение. В нем уменьшается доля факторов научной новизны исследований, и возрастает содержание, связанное с пониманием исследовательской деятельности как инструмента повышения качества образования.

\section{Список используемых источников:}

1. Обухов А.С. Исследовательская позиция и исследовательская деятельность: что и как развивать? // Исследовательская работа школьников. 2003. №4. С. 18-23. 
2. Пинский А.А., Абатурова В.В., Дерзкова Н.П. Предпрофильная подготовка учащихся 9-х классов общеобразовательных учреждений. Итоги эксперимента и перспективы дальнейшего развития. М.: Альянс-Пресс, 2004. 160 с.

3. Поддьяков А.Н. Исследовательское поведение, интеллект и творчество // Исследовательская работа школьников. 2002. №2. С. 29-42.

(C) 2015, Саттарова B.C.

Организация исследовательской деятельности студентов колледжей через систему зачетных единиц на примере предмета: математика
(C) 2015, Sattarova V.S.

Organization of research activities of college students through a system of credits as an example the subject of mathematics 